\title{
Manipulation of the human gut microflora
}

\author{
BY JEAN-CLAUDE RAMBAUD, YORAM BOUHNIK, \\ PHILIPPE MARTEAU AND PHILIPPE POCHART \\ Service de Gastroentérologie et Unité INSERM 290, Hôpital Saint-Lazare, Paris, France
}

Manipulation of the human gut microflora is being attempted as a means of introducing into the digestive tract new micro-organisms which are beneficial to the host or which are able to bring about advantageous changes to the equilibrium populations and metabolic activities of the indigenous flora. In theory, this can be achieved by ingestion of nutrients or growth substances specifically favouring certain species, or by administration of exogenous selected micro-organisms. These micro-organisms, through their own complement of enzymes, may be able to compensate for some deficient intestinal enzyme activities of the host. However, the administration of the exogenous flora is primarily aimed at improving the digestive flora acquired under abnormal conditions, such as (a) inadequate transfer of micro-organisms from the mother to the infant in a highly hygienic environment. (b) consumption of sterile or nearly sterile food, (c) frequent antibiotic treatment (Fuller, 1991). Improvement in the resistance of the host to intestinal pathogens, whether by a 'barrier' effect of the flora or by stimulation of the immune system, and alteration of the profile of the colonic flora and its enzymic capacity are among the most widely investigated putative effects of exogenous micro-organisms. A few studies, which have dealt with their potential extra-gastrointestinal actions will not be reviewed here (see Marteau et al. 1993).

Micro-organisms that are likely to be used to achieve these goals have been called probiotics, i.e. 'live microbial feed supplements which beneficially affect the host animal (or human) by improving its microbiological balance' (Fuller, 1991). However, some of the putative effects of probiotics are beyond the limits of this definition.

An essential determinant in the choice of a probiotic is its ability to survive in the environment where it is intended to act. Unfortunately, most studies on probiotic actions have ignored this basic requirement. Moreover, a micro-organism cannot affect its environment unless its population reaches a certain minimum level which has not been exactly determined, but is probably about $10^{7}-10^{8} \mathrm{CFU} / \mathrm{g}$ in the large intestine (Ducluzeau \& Raibaud, 1989).

The probiotic preparations currently available are still mainly the lactic acid bacteria and bifidobacteria, which have been used empirically for as long as fermented milk has been consumed (Table 1).

\section{INTESTINAL COLONIZATION BY EXOGENOUS BACTERIA}

Several conditions, some related to the properties of the inoculum, are needed to facilitate prolonged colonization of the intestine by an exogenous bacterium. Being host specific (Conway, 1988) and belonging to a host dominant bacterial genus (Ducluzeau \& Raibaud, 1989) seem to be prerequisites. As suggested by the study of infectious diarrhoeas, the size of the inoculum is probably important. The viability in the upper digestive tract of exogenous bacteria depends on the buffering capacity of the vehicle, 
Table 1. Composition of probiotics

\begin{tabular}{lccc}
\hline Origin ... & Human & Animal & Plant \\
\hline Streptococcus thermophilus & & $\mathrm{X}$ & \\
Lactobacillus bulgaricus & & $\mathrm{X}$ & \\
Lactobacillus acidophilus & $\mathrm{X}$ & $\mathrm{X}$ & \\
Lactobacillus casei (GG) & $\mathrm{X}$ & & \\
Bifidobacterium longum & $\mathrm{X}$ & & \\
Bifidobacterium breve & $\mathrm{X}$ & $\mathrm{X}$ & $\mathrm{X}$ \\
Bifidobacterium animalis & & $\mathrm{X}$ & $\mathrm{X}$ \\
Streptococcus faecium & & & \\
Saccharomyces boulardii & & \\
Saccharomyces cerevisiae & & \\
\hline
\end{tabular}

the capacity of the micro-organism to resist acid (Conway et al. 1987; Pochart et al. 1989) and possibly other upper digestive secretions. This resistance is mainly a function of its cell wall stability.

Adhesion to the intestinal mucosa is probably a major determinant of colonization by the exogenous strains (Conway, 1988). Compared with the great deal of knowledge concerning pathogens, little is known about the adhesion capacity and mechanisms of organisms used as probiotics. It has been shown that Lactobacillus spp. may be cultured from human jejunal and colonic mucosa (Conway, 1988) and that this genus of bacteria adhere, to an extent that varies among strains, to human adult ileal cells (Conway et al. 1987) and to human fetal intestinal cells in vitro, but not to Streptococcus thermophilus (Kleeman \& Klaenhammer, 1982).

The mechanisms of adhesion of Lactobacillus spp. to the squamous stomach epithelium of rodents have been studied (Conway, 1988). The role of membrane polysaccharide structures as receptors for adhesion has been questioned, and lipoteichoic acids and bacterial proteins have been proposed as possible alternatives. Surface proteins are probably involved in ileal adhesion of lactobacilli. In the large intestine, bacteria adhered to the mucosa by a chemotaxic mechanism, attracting them towards the mucus (Ducluzeau \& Raibaud, 1989).

Besides the intrinsic properties of the exogenous organisms, exogenous and host factors could play a major role in the gut. Animal studies have shown the influence of diet and environmental stress (Tannock, 1983); also, the possibility in some cases of immunological modulation has been considered. However, the barrier effect of the indigenous flora is the main factor in the elimination of exogenous micro-organisms. The mechanisms proposed, which are poorly understood at present, include space occupation, competition for substrate, secretion of bacteriocins or other antagonistic proteins, production of antagonistic substrates such as volatile fatty acids and $\mathrm{H}_{2} \mathrm{~S}$ and adverse physico-chemical $(\mathrm{pH}$, redox potential) conditions (Ducluzeau \& Raibaud, 1989). In vivo, these factors usually have a bacteriostatic action on the exogenous micro-organisms, which are cleared at the same rate as an intestinal transit marker.

These numerous obstacles to colonization of the gut by non-pathogenic microorganisms may be responsible for the usual failure of attempts to implant exogenous bacteria. A few studies (Gilliland et al. 1978; Ayebo et al. 1980) have shown faecal excretion, at a high level, of living Lactobacillus acidophilus, in fermented or non- 
fermented milk, but whether the recovered faecal strain was identical to the one ingested usually was not checked.

Attempts to use antibiotics to weaken resistance to colonization within the gut (Barza et al. 1987) failed to promote Lactobacillus spp. implantation (Lidbeck et al. 1988). Interestingly, in a genotypic study with Bifidobacterium spp. by Bouhnik et al. (1992a), no colonization of the distal intestine by the exogenous strain was demonstrated. However, during antibiotic treatment, indigenous strains appeared and remained in the dominant flora at the same population level several weeks after antibiotic treatment had ceased.

These essentially negative results contrast with the successful treatment of relapsing pseudomembranous colitis with human fresh stool or bacterial mixture enemas, which are supposed to restore the barrier against Clostridium difficile (Bowden et al. 1981; Tvede \& Rask-Madsen, 1989). However, a similar attempt to implant an exogenous Bifidobacterium spp. by enema after antibiotic treatment was unsuccessful (Y. Bouhnik, N. Bisetti \& J. C. Rambaud, unpublished results). Similarly, the transient reduction of colonic bacterial mass by oral administration of a polyethylene glycol solution failed to facilitate colonization by the Bifidobacterium spp. previously used in the antibiotic experiments (Bouhnik et al. 1991).

Most of the obstacles for implantation of an exogenous flora in adults theoretically do not exist in the newborn, in whom indigenous flora is absent or limited and in whom the immune mechanisms are not fully developed. It has been shown that very early administration of a strain of human Escherichia coli (the dominant flora at this age), which is without plasmids, is non-toxigenic and sensitive to all the usual antibiotics, it was able in most cases to establish itself for a prolonged time in the dominant flora and to exert a barrier effect on antibiotic-resistant strains of $E$. coli (Duval-Iflah et al. 1982). Unfortunately, few further attempts have been made to go beyond this study of a barrier effect within a species to ascertain its potential as a barrier against challenge from other species, and its possible value in establishing a beneficial flora. Recently, a strain of Bifidobacterium bifidum was implanted in a small proportion of inoculated neonates; no effect of the implanted bacterium was found on the faecal level of enterobacteria or streptococci (Hudault et al. 1993).

\section{SURVIVAL OF INGESTED MICRO-ORGANISMS}

Even in the absence of intestinal colonization, exogenous micro-organisms can exert significant probiotic effects, provided they are in continuous transit in the gut at a sufficient concentration (Fuller, 1991). Currently, all probiotics used in humans act according to the latter mechanism. In contrast to colonization, it is clear that host specificity does not influence the activity of exogenous micro-organisms, as shown by some yogurt bacteria and yeast effects.

Lactobacillus bulgaricus and $S$. thermophilus in pure culture have a poor intrinsic resistance to acid, and are destroyed within a few minutes at $\mathrm{pH} 1$ and in about $1 \mathrm{~h}$ at $\mathrm{pH}$ 3 (Conway et al. 1987). However, yogurt has a potent buffering capacity and, after $430 \mathrm{~g}$ yogurt were ingested by volunteers, the duodenal concentration of viable $L$. bulgaricus was over $10^{5} \mathrm{CFU} / \mathrm{ml}$, i.e. a survival rate of at least $1 \%$ (Pochart et al. 1989). In ileostomists, the concentration of viable $L$. bulgaricus in the ileostomy fluid was $10^{5}-10^{6}$ $\mathrm{CFU} / \mathrm{ml}$ after consumption of yogurt containing $10^{6} \mathrm{CFU} / \mathrm{ml} \mathrm{L}$. bulgaricus (Lindwall \& 
Fonden, 1984). The excretion of yogurt bacteria in faeces cannot be accurately quantified with confidence by the usual techniques.

The intrinsic in vitro capacity for survival of $L$. acidophilus in acid conditions is clearly higher than that of $L$. bulgaricus, although differences among strains do exist. In the stomach, the in vivo survival of $L$. acidophilus is $\mathrm{pH}$-related and is increased by the buffering capacity of milk (Conway et al. 1987), and L. acidophilus ingested in fermented milk has been found to survive well in the proximal (Robins-Browne \& Levine, 1981) and distal small bowel (Marteau et al. 1992). The ileal recovery of the oral inoculum, measured by the intubation technique, is about $1.5 \%$ (Marteau et al. 1992). Studies on the capacity of $L$. acidophilus to survive through the whole human gut have yielded variable results, probably due to differences in strains, inocula and level of indigenous faecal lactobacilli. The ingested dose seems to be an important factor in recovery of viable exogenous lactobacilli in faeces (Gilliland et al. 1978). Based on the findings of Gilliland et al. (1978), the maximal survival rate is $2-5 \%$.

Lactobacillus casei strain GG has been isolated by screening human stools for strains that were resistant to acid and bile (Silva et al. 1987). However, its survival rate through the digestive tract is low, since the lowest dose rate at which strain GG passes into the faeces was $1.5 \times 10^{10} \mathrm{CFU} / \mathrm{d}$ in the majority of volunteers studied (Marteau et al. 1993). After oral ingestion, Lactobacillus strain GG is found in stools, sometimes at very low concentrations, following antibiotic treatment (Siitonen et al. 1990).

In vitro sensitivity of bifidobacteria to acid differs among strains. Some of those used in fermented dairy products are highly resistant, so that they survive passage through the human stomach (Berrada et al. 1991). In two studies using an intestinal perfusion technique, 23.5 (Pochart et al. 1992) and 37.5\% (Marteau et al. 1992) of two strains ingested in fermented milk were recovered in the distal ileum. Owing to the ingested load and ileal fluid flow-rate, the concentration of the two Bifidobacterium strains in ileal fluid reached $2 \times 10^{6} \mathrm{CFU} / \mathrm{ml}$ in both studies. A significant increase in the faecal concentration of bifidobacteria was observed after ingestion of viable bifidobacteria, but whether the strain in faeces was the ingested one was not checked, and the possibility that a 'bifidus growth factor' affected the indigenous flora could not be ruled out (Pochart et al. 1990). By using milk fermented with a selected Bifidobacterium sp. variant that could be distinguished from the indigenous strains, it was shown that the exogenous strain reached a mean level in stools of $6.3 \times 10^{8} \mathrm{CFU} / \mathrm{g}$ for as long as the product was being consumed (Fig. 1). Faecal recovery of the oral load was 30\% (Bouhnik et al. $1992 b$ ). This high value makes bifidobacteria a potentially privileged vector of probiotic actions.

Enterococcus faecium, which showed partial resistance to acid in vitro, was found at low concentrations in the duodenum after ingestion of three tablets containing $10^{7}-18^{8}$ organisms. Faecal counts of $E$. faecium also increased significantly during the period of ingestion (Friis-Moller \& Hey, 1983).

Very little is known about the fate of ingested yeasts in the human gut. During administration of $3 \cdot 2 \times 10^{10} \mathrm{CFU}$ Saccharomyces boulardii for $14 \mathrm{~d}$, steady-state and faecal elimination of living $S$. boulardii was $0 \cdot 36 \%$, and the faecal concentration was $1 \times 10^{7} \mathrm{CFU} / \mathrm{g}$ (Bléhaut et al. 1989).

In summary, several micro-organisms can pass live through the human gastrointestinal tract. The concentrations of exogenous living micro-organisms (or bacterial enzyme activities) at the different levels of the gut are more significant variables than the overall 


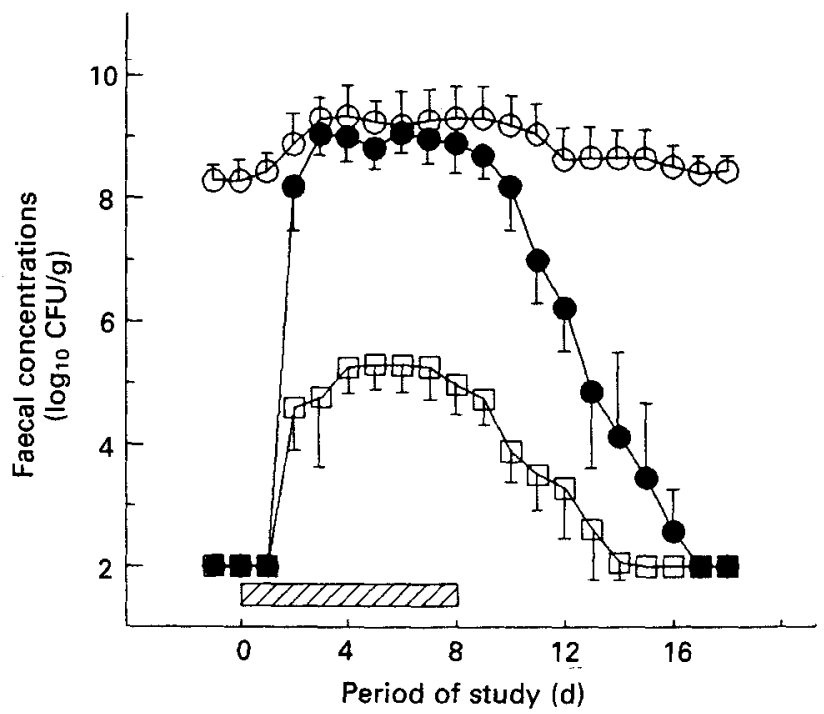

Fig. 1. Faecal concentrations of total bifidobacteria (O), the exogenous strain of Bifidobacterium sp. (O) and spores of Bacillus sterothermophilus (SBS; $\square$ ) obtained in eight healthy volunteers after ingestion of $125 \mathrm{~g}$ three times daily of fermented milk containing $1.6 \times 10^{9} \mathrm{CFU}$ selected exogenous Bifidobacterium $\mathrm{sp} . / \mathrm{g}$ and $3.2 \times 10^{5}$ $\mathrm{CFU}$ SBS/g for $8 \mathrm{~d}$. Values are means with their standard errors represented by vertical bars. (From Bouhnik et al. 1992b.)

percentage of survival. However, from the few findings available, it seems that the main factor governing upper and lower small intestine and faecal concentrations of an exogenous strain is its resistance to upper digestive tract secretions. That the percentage of flowing ingested bacteria remains almost constant from the ileum to the faeces is consistent with there being a bacteriostatic action within the colon.

\section{EFFECTS OF PROBIOTICS IN THE INTESTINE}

\section{Alteration of bacterial flora and its metabolic activities}

Some probiotics are antagonistic in vitro to pathogens or indigenous bacteria, but very few pertinent findings are available on their in vivo action in humans. Administration of lactobacilli has been seen to induce a drop in faecal counts of $E$. coli in some studies (Ayebo et al. 1980; Lidbeck et al. 1987), but not in all (Gilliland et al. 1978).

Changes in the metabolic activities of the indigenous flora during various regimens of probiotic administration are more interesting, as they reflect the variation of whole flora. Significant variations in faecal output of enzymes which could play a role in colonic carcinogenesis (Goldin \& Gorbach, 1976) have been reported during consumption of milk fermented with various lactic acid bacteria (Table 2). In some of these studies a probiotic effect of the vehicle was ruled out. Enzyme levels returned to their basal output within 3 weeks of stopping the administration of exogenous bacteria.

Bifidobacterium longum reduced lactulose-induced $\mathrm{H}_{2}$ breath excretion, but no modification in vitro of lactulose-induced production of $\mathrm{H}_{2}$ or $\mathrm{CH}_{4}$ by the left and right colonic flora was observed during ingestion of L. acidophilus and Bifidobacterium spp. (Marteau et al. 1993). 
Table 2. Effects of lactic acid bacteria ingestion on faecal bacterial enzyme activities in humans

\begin{tabular}{|c|c|c|c|c|c|c|}
\hline Ingested bacteria & $\begin{array}{c}\text { Daily } \\
\text { quantity }\end{array}$ & Subjects & $\begin{array}{c}\text { Azoreductase } \\
(E C 1.6 .6 .7)\end{array}$ & $\begin{array}{c}\text { Nitro- } \\
\text { reductase }\end{array}$ & $\begin{array}{l}\text { Glucu- } \\
\text { ronidase }\end{array}$ & Reference \\
\hline \multicolumn{7}{|l|}{ Lactobacillus } \\
\hline acidophilus $\dagger$ & $10^{9}$ & 12 & ND & ND & $\downarrow *$ & $\begin{array}{l}\text { Ayebo et al. } \\
\quad(1980)\end{array}$ \\
\hline L. acidophilus $\dagger$ & $10^{9}$ & 21 & $\downarrow *$ & $\downarrow *$ & $\downarrow *$ & $\begin{array}{l}\text { Goldin \& } \\
\text { Gorbach } \\
(1984)\end{array}$ \\
\hline L. acidophilust & $10^{9}$ & 7 & $\downarrow *$ & $\downarrow *$ & $\downarrow *$ & $\begin{array}{l}\text { Pedrosa et al. } \\
\quad(1990)\end{array}$ \\
\hline \multicolumn{7}{|l|}{ L. bulgaricus +} \\
\hline thermophilus & $5 \times 10^{8}$ & 9 & - & - & - & $\begin{array}{l}\text { Pedrosa et al. } \\
\text { (1990) }\end{array}$ \\
\hline \multicolumn{7}{|l|}{ L. acidophilus + } \\
\hline + Streptococcus spp. + & $10^{9}-10^{10}$ & 9 & - & $\downarrow *$ & - & $\begin{array}{l}\text { Marteau } \\
\quad \text { et al. }(1990 b)\end{array}$ \\
\hline Bifidobacterium sp. & $10^{10}$ & 6 & - & $\downarrow *$ & $\downarrow *$ & $\begin{array}{l}\text { Bouhnik } \\
\quad \text { (unpublished) }\end{array}$ \\
\hline
\end{tabular}

ND, not determined; -, no effect; $\downarrow$, decrease in activity.

+ No effect with milk or killed bacteria.

* The decrease in activity was significant $(P<0 \cdot 05)$.

\section{Lumen enzyme effects of probiotics}

By using the $\mathrm{H}_{2}$ breath test and intestinal intubation, it has been well established that lactose malabsorbers digest lactose more efficiently from fresh yogurt than from pasteurized yogurt or milk (Marteau et al. 1990a). This is partly due to the presence of a highly active bacterial lactase activity in $L$. bulgaricus and St. thermophilus. It has been shown that this lactase activity is not completely denatured during its passage through the stomach, and can be detected in the human intestine (Kolars et al. 1984; Pochart et al. 1989; Marteau et al. 1990b). This microbial lactase is able to digest lactose in the lumen and, thus, compensate for the mucosal deficiency. Similarly, Harms et al. (1987) demonstrated that in children with sucrase ( $E C$ 3.2.1.48)-isomaltase (EC 3.2.1.10) deficiency, sucrose digestion can be improved by administering Saccharomyces cerevisiae, a yeast which possesses a sucrase 1000 times more active than the sucrase of normal small intestinal mucosa.

Oral administration of $E$. faecium was found in one study to modify the colonic metabolism of bile salts (Salvioli et al. 1982). Recently, it has been shown that a milk fermented with Bifidobacterium spp., Lactobacillus spp. and Streptococcus spp. could deconjugate bile salts in the small bowel. This potentially harmful effect should be further studied (P. Marteau, P. Pochart, Y. Bouhnik \& J. C. Rambaud, unpublished results). 


\section{Parietal effects of bacteria in transit}

Oral administration of $S$. boulardii markedly increased lactase (EC 3.2.1.108), sucrase and maltase ( $E C$ 3.2.1.20) activities in jejunal biopsies, whereas histological morphology and protein content of the mucosa remained unchanged (Buts et al. 1986). These results were interpreted as an effect of the yeast on either the synthesis or catabolism of intestinal disaccharidases. Contrasting with this study, it was subsequently reported that ingestion of fresh yogurt containing viable $L$. bulgaricus and St. thermophilus did not modify significantly lactase activity in the duodenal mucosa of lactose malabsorbers (Lerebours et al. 1989). However, the site studied was perhaps not the best choice, since no spontaneous lactase activity exists in the duodenum of such subjects.

The putative effects of probiotics on the local or systemic immune system in humans is an attractive field of research, but present knowledge relies mainly on animal studies. In humans, ingestion of high doses of L. bulgaricus and St. thermophilus raise the levels of serum $\gamma$-interferon and circulating NK cells (De Simone et al. 1991).

\section{Applications in medicine}

Apart from remedying lactase and sucrase-isomaltase intolerance mentioned previously, probiotics have been largely used in the prevention or treatment of infectious diarrhoeas and antibiotic-related digestive disturbances. In the past papers reporting uncontrolled studies have raised doubt about the value of using probiotics. However, more recent well-controlled studies have provided a few unequivocal positive results (Marteau et al. 1993).

Several studies have demonstrated a protective effect of inoculation with bacteria or $S$. boulardii during antibiotic treatments (Table 3 ). In the management of intestinal infections, two goals can be defined for 'transiting micro-organism therapy', amelioration of symptoms, and elimination of the pathogen. The first goal has been far more frequently attained than the second. Several controllex randomized trials have demonstrated a beneficial effect of yogurt, E. faecium SF68 (Bellomo et al. 1980), L. case $i$ strain GG, or $S$. boulardii for infants recovering from gastroenteritis; however, this is not a general property of all transiting micro-organisms.

Several studies in which transiting micro-organisms were used to prevent traveller's diarrhoea gave negative results. In a trial in subjects travelling to Turkey, $L$. casei strain GG had no significant effect on the overall diarrhoea rate, but a retrospective analysis of the results showed a reduction of the incidence of diarrhoea in a subgroup of travellers to one of the two destinations studied (Oksanen et al. 1990). A double-blind controlled study did not reveal any curative effect of $E$. faecium EF68 for cholera or $E$. coli diarrhoea (Mitra \& Rabbaani, 1990), and treatment with lactobacilli was found to be inefficient in another study as a cure for $E$. coli diarrhoea (Silva et al. 1987). Open trials of several therapies using living micro-organisms to treat intestinal disease caused by C. difficile have suggested that lactobacilli or $S$. boulardii have interesting effects (Marteau et al. 1993); however, controlled studies are not yet available to confirm these results.

In conclusion, it is clear that much more solid scientific work needs to be undertaken before the medical profession can fully recommend probiotics, despite authority of Metchnikoff (1908). We might adapt the well-known legal maxim 'Justice must not only be done, it must be seen to be done' to our present enquiry, thus 'A theory must not only 
Table 3. Randomized controlled studies using transiting micro-organisms to protect from antibiotic-associated diarrhoea (From Marteau et al. 1993)

\begin{tabular}{|c|c|c|c|}
\hline \multirow[b]{2}{*}{ Antibiotic } & \multirow[b]{2}{*}{ Probiotic } & \multicolumn{2}{|c|}{ Incidence of diarrhoea $\dagger$} \\
\hline & & Probiotic & Placebo \\
\hline Ampicillin & Lactine $x^{\mathbb{B}}$ & $8 \cdot 3^{*}$ & $21 \cdot 0$ \\
\hline Neomycin & $\begin{array}{l}\text { Lactobacillus } \\
\text { acidophilus }\end{array}$ & $20 \cdot 0^{*}$ & $42-0$ \\
\hline Erythromycin & Lactobacillus GG & $\ddagger$ & \\
\hline Erythromycin & $\begin{array}{l}\text { Bifidobacterium } \\
\text { longum }\end{array}$ & $\ddagger$ & \\
\hline Antituberculous & $\begin{array}{l}\text { Enterococcus } \\
\text { faecium }\end{array}$ & $5 \cdot 0$ & $18 \cdot 0$ \\
\hline Miscellaneous & $\begin{array}{c}\text { Saccharomyces } \\
\text { boulardii }\end{array}$ & $\ddagger$ & \\
\hline Miscellaneous & S. boulardii & $4 \cdot 5^{*}$ & 17.5 \\
\hline Miscellaneous & S. boulardii & $9 \cdot 5^{*}$ & $21 \cdot 8$ \\
\hline
\end{tabular}

Values were significantly lower than those for the placebo group: $* P<0-05$.

$\uparrow$ Percentage of subjects suffering diarrhoea.

$\$$ Values were significantly lower than those for the placebo group; values not given.

be right, it must be seen to be right'. A rational, rather than an empirical choice of the putative probiotics is obviously advisable. The use of genetically engineered microorganisms that can colonize the gut or pass through it at a high concentration and which also possess useful biological activity, are the most appropriate candidates for achieving this goal.

\section{REFERENCES}

Ayebo, A. D., Angelo, I. A. \& Shahani, K. M. (1980). Effect of ingesting Lactobacillus acidophilus milk upon fecal flora and enzyme actjvity in humans. Milchwissenschaft 35, 730-733.

Barza, M., Giulano, M., Jacobus, N. V. \& Gorbach, S. L. (1987). Effect of broad-spectrum parenteral antibiotics on 'colonization resistance' of intestinal microflora of humans. Antimicrobial agents and Chemotherapy 31, 723-727.

Bellomo, G., Mangliali, A., Nicastro, L. \& Frigerio, G. (1980). A controlled double-blind study of SF68 strain as a new biological preparation for the treatment of diarrhoea in pediatrics. Current Therapeutic Research 28, 927-936.

Berrada, N., Lemeland, J. F., Laroche, G., Thouvenot, P. \& Piaia, M. (1991). Bifidobacterium from fermented milks: survival during gastric transit. Journal of Dairy Science 74, 409-413.

Bléhaut, H., Massot, J., Elmer, G. W. \& Lévy, H. (1989). Disposition kinetics of Saccharomyces boulardii in man and rat. Biopharmaceutics \& Drug Disposition 10, 353-364.

Bouhnik, Y., Mangin, I., Pochart, P., Bisetti, N., Simonet, J. M., Delaris, B. \& Rambaud, J. C. (1992a). Can exogenous bacteria colonize the colonic flora? An in vivo study in man. Gastroenterology 102, A598.

Bouhnik, Y., Pochart, P., Marteau, P., Arlet, G., Goderel, I. \& Rambaud, J. C. (1992b). Fecal recovery in humans of viable Bifidobacterium sp. ingested in fermented milk. Gastroenterology 102, 875-878.

Bouhnik, Y., Pochart, P., Marteau, P., Flourié, B., Goderel, I. \& Rambaud, J. C. (1991). Effect of intestinal microflora modifications on the clearance of an exogenous Bifidobacterium sp. ingested in a fermented dairy product. Gastroenterology 100, A516.

Bowden, T. A., Mansberger, A. R. \& Lykins, L. E. (1981). Pseudomembranous enterocolitis: mechanism of restoring flora homeostasis. Annals of Surgery 47, 178-183. 
Buts, J. P., Bernasconi, P., Van Craynest, M. P., Maldague, P. \& De Meyer, R. (1986). Response of human and rat small intestinal mucosa to oral administration of Saccharomyces boulardii. Pediatric Research 20 , 192-196.

Conway, P. (1988). Lactobacilli: fact and fiction. In Regulatory and Protective Role of the Normal Microflora, pp. 263-281 [D. J. Hentges, editor]. New York: Academic Press.

Conway, P. L., Gorbach, S. L. \& Goldin, B. R. (1987). Survival of lactic acid bacteria in the human stomach and adhesion to intestinal cells. Journal of Dairy Science 70, 1-12.

De Simone, C., Rosati, E., Moretti, S., Bianchi-Salvadori, B., Vesley, R. \& Jirillo, E. (1991). Probiotics and stimulation of the immune response. European Journal of Clinical Nutrition 45, 32-34.

Ducluzeau, R. \& Raibaud, P. (1989). Les intéractions bactériennes dans le tube digestif. Revue Scientifique et Technique de l'Office International des Epizoolus 8, 291-311.

Duval-Iflah, Y., Ouriet, M. F., Moreau, C., Daniel, N., Gabilan, J. C. \& Raibaud, P. (1982). Implantation précoce d'une souche de Escherichia coli dans l'intestin de nouveaux-nés humains: effet de barrière vis-à-vis de souches de E. coli antibiorésistantes. Annales de Microbiologie (Institut Pasteur) 133A, 393-408.

Friis-Moller, A. \& Hey, H. (1983). Colonization of the intestinal canal with a Streptococcus Paecium preparation (Paraghurt ${ }^{8}$ ). Current Therapeutic Research 33, 807-815.

Fuller, R. (1991). Probiotics in human medicine. Gut 32, 439-442.

Gilliland, S. E., Speck, M. L., Nanyok, G. F. J. \& Giesbrecht, F. G. (1978). Influence of consuming non fermented milk containing Lactobacillus acidophilus on fecal flora of healthy males. Journal of Dairy Science 61, 1-10.

Goldin, B. R. \& Gorbach, S. L. (1976). The relationship between diet and rat fecal bacterial enzymes implicated in colon cancer. Journal of National Cancer Institute 25, 371-375.

Goldin, B. R. \& Gorbach, S. L. (1984). The effect of milk and lactobacillus feeding on human intestinal bacterial enzyme activity. American Journal of Clinical Nutrition 39, 756-761.

Harms, H. K., Bertele-Harms, R. M. \& Bruer-Kleis, D. (1987). Enzymes substitution therapy with the yeast Saccharomyces cerevisiae in congenital sucrase-isomaltase deficiency. New England Journal of Medicine 316, 1306-1309.

Hudault, S., Bridonneau, C., Raibaud, P., Chabarret, C. \& Vial, M. F. (1993). Establishment of Bifidobacterium bifidium in the intestine of human neonates: relationship with the bifidus-factors found in the stools. Proceedings of the Nutrition Society. (In the Press)

Kleeman, E. G. \& Klaenhammer, T. R. (1982). Adherence of Lactobacillus species to human fetal intestinal cells. Journal of Dairy Science 65, 2063-2069.

Kolars, J. C., Levitt, M. D., Aouji, M. \& Savaiano, D. A. (1984). Yogurt: an autodigesting source of lactose. New England Journal of Medicine 310, 1-3.

Lerebours, E., N'Djitoyap Ndam, C., Lavoine, A., Hellot, M. F., Antoine, J. M. \& Colin, R. (1989). Yogurt and fermented-then-pasteurized milk: effects of short-term and long-term ingestion on lactose absorption and mucosal lactase activity in lactase-deficient subjects. American Journal of Clinical Nutrition 49, 823-827.

Lidbeck, A., Edlund, C., Gustafsson, J. A., Kager, R. \& Nord, C. E. (1988). Impact of Lactobacillus acidophilus on the normal intestinal microflora after administration of two antimicrobial agents. Infection 16, 329-336.

Lidbeck, A., Gustafsson, J. A. \& Nord, K. E. (1987). Impact of Lactobacillus acidophilus supplements on the human oropharyngeal and intestinal microflora. Scandinavian Journal of Infectious Disease 19, 531-537.

Lindwall, S. \& Fonden, R. (1984). Passage and survival of $L$. acidophilus in the human gastrointestinal tract. International Dairy Federation Bulletin 21, 179.

Marteau, P., Flourié, B., Pochart, P., Chastang, C., Desjeux, J. F. \& Rambaud, J. C. (1990a). Effect of the microbial lactase activity in yogurt on the intestinal absorption of lactose: an in vivo study in lactasedeficient humans. British Journal of Nutrition 64, 71-79.

Marteau, P., Pochart, P., Bouhnik, Y. \& Rambaud, J. C. (1993). Fate and effects of some ingested non pathogenic micro-organisms transiting through the human gut. In World Review of Nutrition and Dietetics [G. H. Bourne, editor]. Basel: S. Karger.

Marteau, P., Pochart, P., Bouhnik, Y., Zidi, S., Goderel, I. \& Rambaud, J. C. (1992). Survie dans l'intestin grêle de Lactobacillus acidophilus et Bifidobacterium sp. ingérés dans un lait fermenté: une base rationnelle à l'utilisation de probiotiques chez l'homme. Gastroenterologie Clinique et Biologique 16, 25-28.

Marteau, P., Pochart, P., Flourié, B., Pellier, P., Santos, L., Desjeux, J. F. \& Rambaud, J. C. (1990b). Effect of chronic ingestion of a fermented dairy product containing Lactobacillus acidophilus and Bifidobacterium bifidum on metabolic activities of the colonic flora in man. American Journal of Clinical Nutrition $\mathbf{5 2}$, $685-688$. 
Metchnikoff, E. (1908). The Prolongation of Life. New York: G. P. Putnam \& Sons.

Mitra, A. K. \& Rabbani, G. H. (1990). A double blind, controlled trial of Bioflorin (Streptococcus faecium SF68) in adults with acute diarrhoea due to Vibrio cholerae and enterotoxigenic Escherichia coli. Gastroenterolgy 99, 1149-1152.

Oksanen, P. J., Salminen, S., Saxelin, M., Hämäläinen, P., Ihantola-Vormisto, A., Muurasniemi-Isoviita, L., Nikkari, S., Oksanen, T., Pörsti, I., Salminen, E., Siitonen, S., Stuckey, H., Toppila, A. \& Vapaatalo, H. (1990). Prevention of traveller's diarrhoea by Lactobacillus GG. Annals of Medicine 22, 53-56.

Pedrosa, M. C., Golner, B., Goldin, B., Baraket, S., Dallal, G. \& Russel, R. M. (1990). Effect of Lactobacillus acidophilus or yogurt feeding on bacterial fecal enzymes in the elderly. Gastroenterology $\mathbf{9 8 ,}$ A439.

Pochart, P., Dewit, O., Desjeux, J. F. \& Bourlioux, P. (1989). Viable starter culture, $\beta$-galactosidase activity, and lactose in duodenum after yogurt ingestion in lactase-deficient humans. American Journal of Clinical Nutrition 49, 828-831.

Pochart, P., Marteau, P., Bisetti, N., Goderel, I., Bourlioux, P. \& Rambaud, J. C. (1990). Isolement des bifidobactéries dans les selles après ingestion prolongée de lait au bifidus. Medecine et Maladies Infectieuses 20, 75-78.

Pochart, P., Marteau, P., Bouhnik, Y., Goderel, I., Bourlioux, P. \& Rambaud, J. C. (1992). Survival of Bifidobacteria ingested in a fermented milk during their passage in the human small intestine: an in vivo study using intestinal perfusion. American Journal of Clinical Nutrition 55, 78-80.

Robins-Browne, R. M. \& Levine, M. M. (1981). The fate of ingested lactobacilli in the proximal small intestine. American Journal of Clinical Nutrition 34, 514-519.

Salvioli, G., Salati, R., Bondi, M., Fratalocchi, A., Sala, B. M. \& Gibertini, A. (1982). Bile acid transformation by the intestinal fora and cholesterol saturation in bile. Effect of Streptococcus faecium administration. Digestion 23, 80-88.

Sitonen, S., Vapaatals, H., Salminen, S., Gordin, A., Saxelin, M., Wikberg, R. \& Kirkkola, A. L. (1990). Effect of Lactobacillus GG yogurt in prevention of antibiotic associated diarrhoea. Annals of Medicine 22, $57-59$.

Silva, M., Jacobus, N. V., Deneke, C. \& Gorbach, S. L. (1987). Antimicrobial substance from a human Lactobacillus strain. Antimicrobial Agents and Chemotherapy 31, 1231-1233.

Tannock, G. W. (1983). Effect of dietary and environmental stress on the gastrointestinal microbiota. In Human Intestinal Microflora in Health and Disease, pp. 517-539 [D. J. Hentges, editor]. New York: Academic Press.

Tvede, M. \& Rask-Madsen, J. (1989). Bacteriotherapy for chronic relapsing Clostridium difficile diarrhoea in six patients. Lancet î, $1156-1160$. 